\title{
The Effects of Problem-Based Learning on Critical Thinking Skills and Student Science Literacy
}

\author{
Suhirman $^{1)^{*}}$, Husnul Khotimah ${ }^{2)}$ \\ Department of Biology Education, Universitas Islam Negeri Mataram, Indonesia \\ Department of Chemistry Education, Universitas Islam Negeri Mataram, Indonesia
}

*Corresponding Author Email: suhirman@uinmataram.ac.id

\author{
Article History \\ Received: March 2020 \\ Accepted: April 2020 \\ Published: June 2020 \\ Key Words \\ Problem-Based Learning; \\ Critical thinking skill; \\ Science literacy
}

How to cite this article?

\begin{abstract}
This study aimed to describe the effect of problem-based learning on students' critical thinking skills and scientific literacy. This research is a quasi-experimental study with pre-test-post test control group design. Sampling was done by saturated sampling technique in which the experimental class consisted of 35 students and the control class was 34 students. Data on critical thinking skills and student scientific literacy were collected using test instruments which were then analyzed descriptively and statistically. The results showed that the Problem-based Learning model had more effect on students' critical thinking and scientific literacy $(p<0.05)$ than conventional learning models applied to the control class. Based on the results of the study, it can be concluded that the Problem-based Learning model significantly effect on students' critical thinking and science literacy in class XI MAN 1 Mataram.
\end{abstract}

Suhirman, S., \& Khotimah, H. (2020). The Effects of Problem-Based Learning on Critical Thinking Skills and Student Science Literacy. Lensa: Jurnal Kependidikan Fisika, 8(1), 31-38. doi:https://doi.org/10.33394/j$\underline{1 \mathrm{kf} . v 8 \mathrm{i} 1.2794}$

\section{INTRODUCTION}

Every citizen has a responsibility to have the scientific knowledge base needed to run a life and make every decision in his life. The rapid development of science and technology requires a person to have certain skills needed to survive. Science education contributes to developing the ability to understand the most effective ways to use science in everyday life and social responsibility (Drago \& Mih, 2015).

Science education has a very important and beneficial role in supporting life and contributing to developing science in general. The Indonesian Ministry of Education and Culture has also promoted school literacy programs to increase student literacy. Competitive generation is needed in natural science and technology that refers to the ability of scientific literacy (Setiawan et al., 2017). This thought underlies the idea of scientific literacy. One of the most important goals of Science Education is the development of scientific literacy (Drago \& Mih, 2015). The importance of scientific literacy in Indonesia contributes to the development of science education. Therefore, scientific literacy has been recognized internationally as a benchmark for the quality level of educational science (Ardianto \& Rubini, 2016). The Program for International Student Assessment (PISA) showed that Indonesia received an average scientific literacy score of 403 with an average score of all 493 participants in 2015 (OECD, 2016). This data shows that Indonesian students are still weak in mastering science.

The study results showed that almost half of Indonesian high school students (41\%) only had limited knowledge about science (Widowati et al., 2017). It was further 
revealed that there were no students who were consistently able to identify, explain, and apply scientific concepts in more complex life problems. One of the weaknesses of intermediate science teachers today is the weak ability to develop integrated science learning (Rubini et al., 2018). Therefore, in learning science, a teacher needs to develop student literacy in order to obtain success both in learning and in real life (Asrizal et al., 2018).

Literacy is important for students to know, understand, and apply science and technology. Science literacy describes a person's ability to understand about laws, theories, concepts, principles, propositions and various other scientific phenomena. The teaching of science should lead to the formation of students' scientific literacy, apparently not yet fully understood by science teachers (Widowati et al., 2017).

The skills needed to face the challenges of the 21 st century are not only teaching, reading, writing and arithmetic but also about developing thinking skills into critical thinking skills. Thinking skills are the main competencies for solving problems, especially higher order thinking skills (Puspitawati et al., 2018). Critical thinking becomes very important because real problems in today's life are increasingly complex (Mutakinati et al., 2018). Higher-order thinking skills are needed to overcome the problems of daily life (Putra et al., 2018). The ability to think scientifically can be considered as part of critical thinking (Suciati et al., 2018). There are 4 skills needed for the 21st century generation known as $4 \mathrm{C}$, namely creativity and innovation, critical thinking and problem solving, communication, and collaboration (creativity and innovation, critical thinking and problem solving, communication, and collaboration) (Astuti et al., 2019; Bedir, 2019). Critical thinking, as one of the main thinking skills, is considered as one of the 21 st century skills that must be included in education (Aljaafil \& Şahin, 2019).

In biology learning activities, the improvement of students' critical thinking skills has not received serious attention from the teachers. Critical thinking skills are the basic skills possessed by students to adapt to 21 st century external challenges (Putra et al., 2018). One of the life skills that are highly needed in the era of globalization is critical thinking skills (Bustami et al., 2018; Anazifa \& Djukri, 2017; Khasanah et al., 2017). Critical thinking skills are one of the important skills in entering the workforce and in living life, so that the quality of human life can be better.

Every level of education has an important role in improving students' critical thinking skills, especially biology students. The short-term goal of critical thinking skills is to strengthen students' conceptual understanding especially on Natural Sciences (IPA) subjects (Khasanah et al., 2017). Learning activities in schools have not been able to optimally increase students' critical thinking (Anazifa \& Djukri, 2017). Required use of learning models such as Problem Based Learning (PBL) (Kurniawan et al., 2019).

Critical thinking is the ability to evaluate or assess the credibility, validity and value of something (Aljaafil \& Şahin, 2019). The formation of character is very important and immediately carried out (Martini et al., 2018). The novelty of this research occurs in the development and formation of student character through problembased learning combined with critical thinking skills and scientific literacy. Character is often also equated with morality or character (Machin, 2014). Character education should touch the three aspects above (head, heart, hand) through habituation (Machin, 2014).

Critical thinking, fostering independence. One of the innovative teaching methods that can be implemented in Biology learning is problem-based learning (PBL). Students' thinking skills can also be developed by applying the Problem-Based Learning (PBL) model (Nuswowati et al., 2017). Indicators of low quality education can be 
considered from the strategies, methods, models and ways of teaching teachers. In general, the learning process at the secondary and high school levels tends to use conventional learning such as lectures, assignments, using textbooks that are more dominated by teachers and passive students in learning. Learning is not directed to find problems and get solutions, nor is it directed towards students' real lives. The 2013 curriculum provides alternative learning strategies for teachers and students. Teachers should be more creative, to foster student activity (Sada, 2019). PBL is a studentcentered approach and requires prior general knowledge. Students are more active in obtaining information from various sources. Since it was first applied until now problembased learning (PBL) has become one of the methods that has received considerable attention in Indonesia, especially in the world of secondary and higher education.

In PBL, students work together in groups to both find and solve problems and make decisions (Haji et al., 2015). PBL is a model that prioritizes the suitability of learning with things that are found in the daily lives of students (Nuswowati et al., 2017). This is in line with the enactment of the 2013 curriculum which recommends learning be carried out with a scientific approach through the PBL method. Problem-based learning (PBL), able to improve and develop knowledge, competencies, problem solving and communication skills (Delaney et al., 2017).

Designing and systematically intervening in learning to create a learning environment needs to be carried out and researched on its effectiveness in developing students' thinking skills (Delaney et al., 2017). In the context of this study, instructional intervention is to add character content in the syntax of problem based learning so that it is referred to as problem-based learning with character emphasis. It is a problem based learning strategy that is designed by sharpening the stages of learning activities to strengthen the character of students and to diversify the meaning of PBL learning syntax so that it leads to the formation of student character. Thus, the stages of learning in problem-based learning with character emphasis are enriched with activities that encourage students to practice forming their character consciously or unconsciously, without leaving the meaning of PBL syntax.

Problem-based learning is a learning model designed in a learning procedure that begins with a specific problem. PBL requires students to independently compile knowledge or collaborate in groups to find a real solution to a problem. Complex, contextual, and structural problems will provide opportunities for students to develop analytical, evaluative, and reflective thinking skills and develop their creativity in exploring various information, developing various possible solutions, and creating various sources in order to solve problems that must be solved (Tsai \& Chiang, 2013). PBL increases student confidence, provides a supportive environment that encourages teamwork, enhances interpersonal communication and problem solving skills, and fosters self-awareness (Moody et al., 2018; Aldarmahi, 2016). According to Aldarmahi (2016), PBL is beneficial for students in compiling their knowledge, developing the reasoning process, improving independent learning skills, and increasing their intrinsic motivation for learning. This study looks for the influence of Problem-Based Learning on critical thinking skills and scientific literacy of students in biology subjects in Madrasah Aliyah.

\section{METHOD}

This research is a quasi-experimental research. The design used in this study is the pre-test post-test control group design. Pre-test post-test control group design is a study conducted twice, namely before the experiment (pre-test), and after the experiment (posttest). The population of this study was students of class XI MAN 1 Mataram. Sampling 
is done by saturated sampling technique. Class XI IPA6 was selected as an experimental class with 35 students, class XI IPA2 was selected as a control class with a number of students 34 . Homogeneity tests were performed to find out that two or more data groups came from populations that had the same variance. Based on homogeneity test results for the experimental class obtained sig: $0.165>0.05$ and control class sig: $0.215>0.05$ which means that the data group or sample is homogeneous.

The initial measurement of critical thinking skills is done before the learning treatment. The learning was conducted by biology teachers in each madrasa ten times. After the learning treatment, final measurements of critical thinking skills and student scientific literacy are carried out.

Data on critical thinking skills scores and students' scientific literacy scores were analyzed with descriptive and inferential statistics. Descriptive statistical analysis to get a descriptive picture of the level of critical thinking skills and student scientific literacy. Inferential statistics with MANOVA to test the research hypothesis at a significance level of 0.05 .

\section{RESULTS AND DISCUSSION}

In general, the results of the study described in this section, namely the score of achievement of critical thinking and scientific literacy of students between the experimental class and the control class. The results of the study are presented in Table 1.

Table 1. Description of the Pretest and Posttest of Experiment and Control Class

\begin{tabular}{lccccccccc}
\hline & \multicolumn{4}{c}{ Experiment class } & \multicolumn{4}{c}{ Control class } \\
\cline { 2 - 9 } \multicolumn{1}{c}{ Description } & CR & SL & CR & SL & CR & SL & CR & SL \\
\cline { 2 - 9 } Total students & 35 & 35 & 35 & 35 & 34 & 34 & 34 & 34 \\
Maximum score & 79 & 79 & 96 & 94 & 65 & 75 & 88 & 81 \\
Minimum score & 44 & 44 & 56 & 50 & 30 & 31 & 42 & 38 \\
Average & 60.79 & 57.35 & 76.97 & 73.59 & 50.00 & 52.82 & 62.09 & 60.67 \\
SD & 8.06 & 9.88 & 12.33 & 13.86 & 8.43 & 10.25 & 14.03 & 12.79 \\
\hline
\end{tabular}

Based on the prerequisite tests, critical thinking data and scientific literacy in this study have normal data, homogeneous variants and homogeneous variant matrices. So Manova analysis for hypothesis testing can be continued. The first hypothesis testing uses the multivariate test presented in Table 2.

Table 2. Multivariate Test hypothesis test

\begin{tabular}{llrrrrr}
\hline Effect & & \multicolumn{3}{c}{ Hypothesis } \\
& & Value & $\mathrm{F}$ & $\mathrm{df}$ & Error df & Sig. \\
\hline Intercept & Pillai's Trace & .977 & $1355.952^{\mathrm{a}}$ & 2.000 & 64.000 & .000 \\
& Wilks' Lambda & .023 & $1355.952^{\mathrm{a}}$ & 2.000 & 64.000 & .000 \\
& Hotelling's Trace & 42.373 & $1355.952^{\mathrm{a}}$ & 2.000 & 64.000 & .000 \\
& Roy's Largest Root & 42.373 & $1355.952^{\mathrm{a}}$ & 2.000 & 64.000 & .000 \\
Class & .307 & $14.172^{\mathrm{a}}$ & 2.000 & 64.000 & .000 \\
& Pillai's Trace & .693 & $14.172^{\mathrm{a}}$ & 2.000 & 64.000 & .000 \\
& Wilks' Lambda & .443 & $14.172^{\mathrm{a}}$ & 2.000 & 64.000 & .000 \\
& Hotelling's Trace & .443 & $14.172^{\mathrm{a}}$ & 2.000 & 64.000 & .000 \\
& Roy's Largest Root & .43 & & & \\
\hline
\end{tabular}

Based on the Table 2 above, it was found that a significant value of sig $=0.00$ $<0.05$. This means that there is a significant influence on the Problem-based Learning 
model of critical thinking and sanitation literacy in a multivariate manner. The second and third hypothesis test analysis can be seen in Table 3.

Table 3. Hypothesis test Tests of Between-Subjects Effect

\begin{tabular}{|c|c|c|c|c|c|c|}
\hline Source & Dependent Variable & $\begin{array}{l}\text { Type III } \\
\text { Sum of } \\
\text { Squares }\end{array}$ & $\mathrm{df}$ & $\begin{array}{c}\text { Mean } \\
\text { Square }\end{array}$ & $\mathrm{F}$ & Sig. \\
\hline \multirow[t]{2}{*}{ Corrected Model } & Critical thinking & $3707.705^{a}$ & 1 & 3707.705 & 21.298 & .000 \\
\hline & Science literacy & $2796.073^{b}$ & 1 & 2796.073 & 15.695 & .000 \\
\hline \multirow[t]{2}{*}{ Intercept } & Critical thinking & 323841.019 & 1 & 323841.019 & 1860.218 & .000 \\
\hline & Science literacy & 301841.088 & 1 & 301841.088 & 1694.335 & .000 \\
\hline \multirow[t]{2}{*}{ Class } & Critical thinking & 3707.705 & 1 & 3707.705 & 21.298 & .000 \\
\hline & Science literacy & 2796.073 & 1 & 2796.073 & 15.695 & .000 \\
\hline \multirow[t]{2}{*}{ Error } & Critical thinking & 11315.698 & 65 & 174.088 & & \\
\hline & Science literacy & 11579.569 & 65 & 178.147 & & \\
\hline \multirow[t]{2}{*}{ Total } & Critical thinking & 339972.000 & 67 & & & \\
\hline & Science literacy & 317152.000 & 67 & & & \\
\hline \multirow[t]{2}{*}{ Corrected Total } & Critical thinking & 15023.403 & 66 & & & \\
\hline & Science literacy & 14375.642 & 66 & & & \\
\hline
\end{tabular}

Based on the results of Table 3 above, it can be seen that the significant value obtained in critical thinking and scientific literacy is smaller than 0.05 , so that the second hypothesis $\mathrm{Ho}$ is rejected and $\mathrm{Ha}$ is accepted, this means that there is a significant influence on the Problem-based Learning model of critical thinking. Likewise with the third hypothesis Ho is rejected and Ha is accepted, in the sense that there is a significant effect of the Problem-based Learning model of learning on scientific literacy.

The results of the overall hypothesis testing that have been described previously show that the Problem-based Learning learning model is proven to have a superior effect on critical thinking and scientific literacy of students compared to the regular learning model. Learning model Project-based learning can influence the creativity of thinking, because in the learning process are trained to improve students' critical thinking, starting from giving ideas, and also in the process of working in worksheets in groups having the same problem so students can correct each other when the presentation takes place, and the model Project-based learning can also affect students' scientific literacy. It can be seen when the process of finding a problem so that students are finally able to solve the problem.

Integrated science learning through guided guided models can increase students' scientific literacy with the acquisition of 0.37 (moderate) category), while using problembased learning models can increase scientific literacy with a gain of 0.41 (medium category). It can be concluded that the two models of guided discovery and problembased learning can improve students' scientific literacy (Ardianto \& Rubini, 2016).

The Science, Technology, Society (STS) model is more successful in increasing students' scientific literacy compared to the PBL model. Scientific literacy for high level students is better when learning to use STS learning models, conversely, for low level it is recommended to apply PBL models in increasing their scientific literacy (Ratini et al., 2018). Its use is the integration of effective science teaching materials through scientific approaches to increase student knowledge and literacy (Asrizal et al., 2018). Training programs can increase teachers' knowledge about science literacy and integrated science learning concepts, as well as teacher skills in designing integrated science learning (Rubini et al., 2018).

Research shows that there are significant differences between biological literacy and critical thinking skills between students who are taught with social-biological case- 
based learning and lecture-based learning (Suwono et al., 2017). The local wisdom-based science module developed is suitable for improving theoretical and empirical students' scientific literacy abilities (Setiawan et al., 2017). The profile of class XI students has the ability to think scientifically through the implementation of scientific approaches is in the low category (Suciati et al., 2018). Critical thinking cannot be transferred through text books, but is needed through thinking (Aljaafil \& Şahin, 2019). Critical thinking is not only about teaching students how to think but also training elastic and active to think, investigate and examine information or new and old facts learned (Aljaafil \& Şahin, 2019). Critical thinking skills achieved by a student in Indonesia through both the implementation of the PjPBL model and the Problem Posing learning did not have a significant difference (Rochmawati, Wiyanto, \& Ridlo, 2019). The results of this study indicate that integrated science learning with the local potential of wood carving and pottery has a significant influence on critical thinking skills (Dewi et al., 2017). Inquirybased learning approaches through the Model of Education Reconstruction (MER) can develop student scientific literacy (Widowati et al., 2017).

\section{CONSLUSSION}

Based on the results of the study that has been done, it can be concluded that there is a significant effect of the Problem-based Learning model on critical thinking and student literacy in class XI MAN 1 Mataram.

\section{REFERENCES}

Aljaafil, E., \& Şahin, M. (2019). Critical thinking skills for primary education: the case in Lebanon. Turquoise International Journal of Educational Research and Social Studies Turquoise International Journal of Educational Research and Social Studies ISSN:, 1(1), $1-7$.

Anazifa, R. . and, \& Djukri. (2017). Project- Based Learning and Problem- Based Learning: are They Effective to Improve Student ' S Thinking Skills. Jurnal Pendidikan IPA Indonesia, 6(2), 346-355. https://doi.org/10.15294/jpii.v6i2.11100

Ardianto, D., \& Rubini, B. (2016). Comparison of students' scientific literacy in integrated science learning through model of guided discovery and problem based learning. Jurnal Pendidikan IPA Indonesia, 5(1), 31-37. https://doi.org/10.15294/jpii.v5i1.5786

Asrizal, Amran, A., Ananda, A., Festiyed, F., \& Sumarmin, R. (2018). The development of integrated science instructional materials to improve students ' digital literacy in scientific approach. Jurnal Pendidikan IPA Indonesia, 7(4), 442450. https://doi.org/10.15294/jpii.v7i4.13613

Astuti, A. ., Aziz, A., Sumarti, S. ., \& Bharati, D. A. . (2019). Preparing 21st century teachers: implementation of 4C character's pre-service teacher through teaching practice preparing 21st century teachers: implementation of $4 \mathrm{c}$ character's preservice teacher through teaching practice. Journal of Physics: Conference Series, 1233, 1-8. https://doi.org/10.1088/1742-6596/1233/1/012109

Bedir, H. (2019). Pre-service ELT teachers' beliefs and perceptions on 21st century learning and innovation skills (4Cs). Journal of Language and Linguistic Studies, 15(1), 231-246. https://doi.org/10.17263/j1ls.547718

Bustami, Y., Syafruddin, D., \& Afriani, R. (2018). The implementation of contextual learning to enhance biology students' critical thinking skills. Jurnal Pendidikan IPA Indonesia, 7(4), 451-457. https://doi.org/10.15294/jpii.v7i4.11721

Delaney, Y., Pattinson, B., Mccarthy, J., \& Beecham, S. (2017). Transitioning from traditional to problem-based learning in management education: the case of a 
frontline manager skills development programme. Innovations in Education and Teaching International, 54(3), 214-222.

Dewi, I. P. M., Suryadarma, I. G. P., Wilujeng, I., \& Wahyuningsih, S. (2017). The effect of science learning integrated with local potential of wood carving and pottery towards the junior high school students ' critical thinking skills. Jurnal Pendidikan IPA Indonesia, 6(1), 103-109. https://doi.org/10.15294/jpii.v6i1.9598

Drago, V., \& Mih, V. (2015). Scientific Literacy in School. Procedia: Social and Behavioral Sciences, 209(July), 167-172. https://doi.org/10.1016/j.sbspro.2015.11.273

Haji A.G, Safriana, \& Safitri R. (2015). The Use of Problem Based Learning to Increase Students' Learning Independent and to Investigate Students' Concept Understanding on Rotational Dynamic at Students of SMA Negeri 4 Banda Aceh. Jurnal Pendidikan IPA Indonesia, 4(1), 67-72. https://doi.org/10.15294/jpii.v4i1.3503

Khasanah, A. N., Sajidan, \& Widoretno, S. (2017). Effectiveness of critical thinking indicator-based module in empowering student' $\mathrm{s}$ learning outcome in. Jurnal Pendidikan IPA Indonesia, 6(1), 187-195. https://doi.org/10.15294/jpii.v6il.8490

Kurniawan, E., Muslim, S., Rahmadyanti, E., Aribowo, W., Kusumawati, N., Ismayati, E., \& Basuki, I. (2019). Vocational students readiness in the face of the Industrial Revolution 4.0 and the demands of life in the 21st Century Skills. Celebes Education Review, 1(1), 40-52.

Machin, A. (2014). Implementasi pendekatan saintifik, penanaman karakter dan konservasi pada pembelajaran materi pertumbuhan. Jurnal Pendidikan IPA Indonesia, 3(1), 28-35.

Martini, Rosdiana, L., Subekti, H., \& Setiawan, B. (2018). Strengthening students' characters and ecopreneurship through science, environment, technology, and society course. Jurnal Pendidikan IPA Indonesia, 7(2), 162-171. https://doi.org/10.15294/jpii.v7i2.14338

Mutakinati, L., Anwari, I., \& Yoshisuke, K. (2018). Analysis Of Students' Critical Thinking Skill of Middle School Through STEM Education Project-Based Learning. Jurnal Pendidikan IPA Indonesia, 7(1), 54-65. https://doi.org/10.15294/jpii.v7i1.10495

Nuswowati, M., Susilaningsih, E., Ramlawati, \& Kadarwati, S. (2017). Implementation of problem-based learning with green chemistry vision to improve creative thinking skill and students ' creative actions. Jurnal Pendidikan IPA Indonesia, 6(2), 221-228. https://doi.org/10.15294/jpii.v6i2.9467

Puspitawati, R. P., Yuanita, L., Rahayu, Y. S., Indana, S., \& Susiyawati, E. (2018). Two problem solving cycles to achieve learning outcomes of thinking skills and plant anatomy concept mastery. Jurnal Pendidikan IPA Indonesia, 7(3), 312-321. https://doi.org/10.15294/jpii.v7i3.14295

Putra, B. K. B., Prayitno, B. A., \& Mariadi. (2018). The effectiveness of guided inquiry and instad towards students ' critical thinking skills on circulatory system materials. Jurnal Pendidikan IPA Indonesia, 7(4), 476-482. https://doi.org/10.15294/jpii.v7i4.14302

Ratini, Muchtar, H., Suparman, M. A., Tamuri, A. H., \& Susanto, E. (2018). The influence of learning models and learning reliance. Jurnal Pendidikan IPA Indonesia, 7(4), 458-466. https://doi.org/10.15294/jpii.v7i4.12489

Rochmawati, A., Wiyanto, \& Ridlo, S. (2019). Analysis of 21 st Century Skills of Student on Implementation Project Based Learning and Problem Posing Models in Science Learning. Journal of Primary Education, 9(1), 58-67.

Rubini, B., Pusitasari, I. D., Ardianto, D., \& Hidayat, A. (2018). Science teachers ' 
understanding on science literacy and integrated science learning: lesson from teachers training. Jurnal Pendidikan IPA Indonesia, 7(3), 259-265. https://doi.org/10.15294/jpii.v7i3.11443

Sada, C. (2019). Exploring teaching learning $\mathrm{p}$ rocess in developing higher order thinking skill (HOT) to higher secondary school ( SMA) students in Pontianak. Journal of Education, Teaching, and Learning, 4(1), 228-232.

Setiawan, B., Innatesari, D. K., Sabtiawan, W. B., \& Sudarmin. (2017). The development of local wisdom-based natural science module to improve science literation of students. Jumal Pendidikan IPA Indonesia, 6(1), 49-54. https://doi.org/10.15294/jpii.v6i1.9595

Suciati, Ali, M. N., Imaningtyas, C. D., Anggraini, A. F., \& Dermawan, Z. (2018). The profile of XI grade students ' scientific thinking abilities on scientific approach implementation. Jurnal Pendidikan IPA Indonesia, 7(3), 341-346. https://doi.org/10.15294/jpii.v7i3.15382

Suwono, H., Pratiwi, H. ., Susanto, H., \& Susilo, H. (2017). Enhancement of student' biological literacy and critical thinking of biology through socio-biological. Jurnal Pendidikan IPA Indonesia, 6(2). https://doi.org/10.15294/jpii.v6i2.9622

Widowati, A., Anjarsari, P., Rahardjo, S. B., \& Elfi, V. H. (2017). The Development of Scientific Literacy through Nature of Science ( NoS ) within Inquiry Based Learning Approach The Development of Scientific Literacy through Nature of Science ( NoS ) within Inquiry Based Learning Approach. Journal of Physics: Conference Series, 909, 1-7 